\title{
HUBUNGAN APGAR SKOR DAN BERAT BADAN LAHIR DENGAN SEPSIS NEONATORUM
}

\author{
${ }^{1}$ Winny Carolus \\ 2Johnny Rompis \\ ${ }^{3}$ Rocky Wilar

\begin{abstract}
Bagian Ilmu Kesehatan Anak Fakultas Kedokteran Universitas Sam Ratulangi Manado Email: cchiwyn@yahoo.com
\end{abstract}

\begin{abstract}
Neonatal sepsis is still a major problem in the field of neonatal care and services. The incidence of sepsis in developing countries is high at 1.8 to 18 per 1000 live births with a mortality rate of $12-68 \%$. This happens because many risk factors for infection in the perinatal period that can not be prevented and addressed. Some of the risk factors associated with sepsis are Apgar scores and birth weight. The purpose of this study was to determine the relationship between Apgar scores and birth weight with sepsis. The research method used is analytic observational prospective study conducted in the department of Prof.Dr.RD Kandou Neonati Subdivision Manado during November 2012 to January 2013. Research subjects are babies with sepsis and not sepsis. The result showed 50 infants suspected sepsis. 40 infants with proven sepsis and 10 infant sepsis. By using the Fisher Exact test and multiple logistic regression analysis found $(p=0.999>\alpha=0.05(R)=0.377)$. The conclusion of this study is that the data obtained from infants with neonatal sepsis have low Apgar scores and low birth weight with the highest percentage. With a statistical test there was no correlation between Apgar scores and birth weight with neonatal sepsis.
\end{abstract}

Keywords: neonatal sepsis, Apgar scores, birth weight

\begin{abstract}
Abstrak: Sepsis neonatorum masih merupakan masalah utama di bidang pelayanan dan perawatan neonatus. Angka kejadian sepsis di negara berkembang cukup tinggi yaitu 1,8-18 per 1000 kelahiran hidup dengan angka kematian sebesar $12-68 \%$. Hal ini terjadi karena banyak faktor risiko infeksi pada masa perinatal yang belum dapat dicegah dan ditanggulangi. Beberapa faktor resiko yang berhubungan dengan sepsis yaitu Apgar skor dan berat badan lahir. Tujuan penelitian ini ialah untuk mengetahui hubungan antara apgar skor dan berat badan lahir dengan sepsis. Metode penelitian yang digunakan yaitu analitik observasional dengan studi prospektif yang dilakukan di Sub Bagian Neonati RSUP Prof.Dr.R.D.Kandou Manado selama bulan November 2012 sampai Januari 2013. Subjek penelitian ialah bayi dengan terbukti sepsis dan tidak sepsis. Hasil penelitian didapatkan 50 bayi tersangka sepsis. 40 bayi dengan terbukti sepsis dan 10 bayi tidak sepsis. Dengan menggunakan uji Fisher Exact dan analisis regresi logistik multipel didapatkan $(p=0,999>\alpha=$ $0,05(\mathrm{R})=0,377)$. Kesimpulan penelitian ini ialah dari data diperoleh bayi dengan sepsis neonatorum memiliki apgar skor rendah dan berat badan lahir rendah dengan persentase terbanyak. Dengan uji statistik tidak terdapat hubungan antara Apgar skor dan berat badan lahir dengan sepsis neonatorum.
\end{abstract}

Kata kunci : sepsis neonatorum, Apgar skor, berat badan lahir

Sepsis neonatorum sampai saat ini masih merupakan masalah utama di bidang pelayanan dan perawatan neonatus. Menurut perkiraan World Health
Organization (WHO), terdapat 5 juta kematian neonatus setiap tahun dengan angka mortalitas neonatus (kematian dalam 28 hari pertama kehidupan) adalah 
34 per 1000 kelahiran hidup, dan 98\% kematian tersebut berasal dari negara berkembang. Secara khusus angka kematian neonatus di Asia Tenggara adalah 39 per 1000 kelahiran hidup. Dalam laporan WHO yang dikutip dari State of the world's mother 2007 (data tahun 20002003) dikemukakan bahwa $36 \%$ dari kematian neonatus disebabkan oleh penyakit infeksi, diantaranya : sepsis; pneumonia; tetanus; dan diare. Sedangkan 23\% kasus disebabkan oleh asfiksia, 7\% kasus disebabkan oleh kelainan bawaan, $27 \%$ kasus disebabkan oleh bayi kurang bulan dan berat badan lahir rendah, serta $7 \%$ kasus oleh sebab lain. ${ }^{1}$

Sepsis neonatal adalah sindrom klinik penyakit sistemik, disertai bakteremia yang terjadi pada bayi dalam satu bulan pertama kehidupan. Angka kejadian sepsis neonatal adalah 1-10 per 1000 kelahiran hidup, dan mencapai 13-27 per 1000 kelahiran hidup pada bayi dengan berat < 1500 gram. Beberapa faktor resiko yang berhubungan dengan sepsis diantaranya Apgar skor dan berat badan lahir. ${ }^{2}$

Berdasarkan latar belakang di atas penilaian Apgar skor dan berat badan mempengaruhi terjadinya sepsis neonatorum. Tetapi penelusuran pustaka mengenai Apgar skor dan berat badan lahir dengan sepsis neonatorum sulit dijumpai di Indonesia. Maka peneliti tertarik untuk melakukan penilitian mengenai hubungan Apgar skor dan berat badan lahir dengan sepsis neonatorum di Sub Bagian Neonati IKA FK Universitas Sam Ratulangi, RSUP Prof.Dr.R.D.Kandou Manado.

Rumusan masalah pada penelitian ini apakah terdapat hubungan antara Apgar skor dan berat badan lahir dengan sepsis neonatorum?

Hipotesis penelitian : terdapat hubungan antara Apgar skor dan berat badan lahir dengan sepsis neonatorum dan hipotesis statistic, dimana $\mathrm{H}_{0}$ : Tidak ada hubungan antara Apgar skor dengan sepsis neonatorum, $\mathrm{H}_{1}$ : Ada hubungan antara Apgar skor dengan sepsis neonatorum, $\mathrm{H}_{0}$ : Tidak ada hubungan antara berat badan lahir dengan sepsis neonatorum, $\mathrm{H}_{1}$ : Ada hubungan antara berat badan lahir dengan sepsis neonatorum. Penelitian ini bertujuan untuk mengetahui hubungan Apgar skor dengan sepsis neonatorum, hubungan berat badan lahir dengan sepsis neonatorum serta hubungan Apgar skor dan berat badan lahir dengan sepsis neonatorum. Diharapkan penelitian ini dapat bermanfaat untuk menambah pengetahuan penulis dan pembaca mengenai hubungan Apgar skor dan berat badan lahir dengan sepsis neonatorum serta sebagai bahan acuan untuk penelitian selanjutnya.

\section{Sepsis neonatorum}

Sepsis neonatorum merupakan istilah yang telah digunakan untuk menggambarkan respons sistemik terhadap infeksi pada bayi baru lahir. Angka sepsis neonatorum meningkat secara bermakna pada bayi dengan berat badan lahir rendah dan bila ada faktor resiko ibu (obstetrik) atau tandatanda koriamnionitis, seperti ketuban pecah lama (>18 jam), demam intrapartum ibu $\left(>37,5^{\circ} \mathrm{C}\right)$, leukositosis ibu $\left(>18000 / \mathrm{mm}^{3}\right)$, pelunakan uterus dan takikardi janin (>180 kali/menit). Faktor resiko host meliputi jenis kelamin lakilaki, cacat imun didapat atau kongenital, galaktosemia (Escherichia coli) pemberian preparat besi intramuskuler (E.coli), anomali kongenital (saluran kencing, asplenia, myelomeningokel, saluran sinus), omfalitis dan kembar (terutama kembar kedua dari janin yang terinfeksi). Prematuritas merupakan faktor resiko baik pada sepsis awal maupun lanjut. ${ }^{3}$

Kriteria diagnostik ${ }^{4}$ :

Diagnosis tersangka sepsis bila didapatkan 1 faktor +2 faktor minor : Lekosit < $5000 / \mathrm{mm}^{3}$ atau $>30000 / \mathrm{mm}^{3}$, Trombosit < 
$150000 / \mathrm{mm}^{3}$, IT rasio $>0,2$ atau IT rasio $>$ nilai normal sesuai umur, CRP $>1 \mathrm{mg} / \mathrm{dL}$, Kultur darah positif, Hipoglikemia / hiperlikemia, Asidosis metabolic, Kadar bilirubin meningkat

Faktor mayor minor :Faktor mayor : (1)Ruptur membran ibu yang lama > 18 jam (2)Ibu dengan demam intrapartum > $38^{\circ} \mathrm{C}$ (3)Korioamnionitis (4)HR janin > 160x/menit (5)Ketuban berbau.

Faktor minor: (1) Ruptur membran ibu yang lama > 12 jam (2) Ibu dengan demam intrapartum $>37,5^{\circ} \mathrm{C}$ (3) Apgar skor rendah (4) Berat badan lahir sangat rendah (BBLR < 1500 gram) (5) Usia Gravida < 37 minggu (6) Kehamilan ganda (7) Keputihan pada ibu yang tidak diobati (8) Ibu ISK atau tersangka ISK yang tidak diobati. ${ }^{5}$

Apgar skor Nilai apgar dapat digunakan untuk menilai respon resusitasi tetapi tidak untuk menentukan apakah bayi memerlukan resusitasi, langkah mana yang dibutuhkan atau kapan kita menggunakannya. Nilai Apgar yang dinilai pada resusitasi tidak sama dengan nilai Apgar pada bayi baru lahir yang bernapas spontan. Nilai Apgar diperluas dengan menyatakan tindakan resusitasi akan memberikan informasi untuk meningkatkan pelayanan neonatal. ${ }^{6}$

Tabel 1 Penilaian Apgar ${ }^{7}$

\begin{tabular}{|c|c|c|c|}
\hline Tanda & 0 & 1 & 2 \\
\hline $\begin{array}{r}\text { Freksuensi } \\
\text { jantung }\end{array}$ & Tidak ada & Dibawah 100 & Diatas 100 \\
\hline Upayapernapasan & Tidak ada & $\begin{array}{l}\text { Lambat, tidak } \\
\text { teratur }\end{array}$ & $\begin{array}{l}\text { Baik, } \\
\text { menangis }\end{array}$ \\
\hline Tonus otot & Lemah & $\begin{array}{l}\text { Beberapa } \\
\text { fleksi tungkai }\end{array}$ & $\begin{array}{l}\text { Gerakan } \\
\text { aktif }\end{array}$ \\
\hline Respons (kateter) & $\begin{array}{l}\text { Tidak ada } \\
\text { respons }\end{array}$ & Menyeringai & $\begin{array}{l}\text { Batuk atau } \\
\text { bersin }\end{array}$ \\
\hline Warna & Biru, pucat & $\begin{array}{l}\text { Tubuh merah } \\
\text { muda, tungkai } \\
\text { biru }\end{array}$ & $\begin{array}{l}\text { Seluruhnya } \\
\text { merah } \\
\text { muda }\end{array}$ \\
\hline
\end{tabular}

\section{Berat Badan Lahir.}

Berat badan merupakan salah satu indikator kesehatan bayi baru lahir. Rerata berat bayi normal (usia gestasi 37 sampai dengan 41 minggu) adalah 3200 gram. Secara umum bayi berat lahir rendah dan bayi dengan berat lahir berlebih, lebih besar resikonya untuk mengalami masalah. ${ }^{8}$

Faktor yang berhubungan dengan berat badan plasenta, malnutrisi, faktor genetik dan Infeksi. Infeksi virus tertentu berhubungan dengan gangguan pertumbuhan janin. Wanita-wanita dengan status sosioekonomi rendah diketahui melahirkan bayi dengan gangguan pertumbuhan maupun bayi kecil, disamping memiliki insidens infeksi perinatal yang lebih tinggi. Bayi-bayi yang menderita infeksi rubella congenital dan sitomegalovirus (CMV) umumnya terjadi gangguan pertumbuhan janin, tidak tergantung pada umur kehamilan saat mereka dilahirkan.

Berat Badan Lahir dan sepsis

Penelitian yang dilakukan oleh Raden NS, di RSUD Dr. Moewardi selama bulan Oktober - Desember 2007 untuk mengetahui hubungan berat badan lahir rendah dengan Sepsis Neonatorum dilakukan uji statistic dengan uji Chi Square dan uji Koefisien Kontingensi. Hasil penelitian dengan metode Chi Square didapatkan ada hubungan antara bayi berat badan lahir rendah dengan Sepsis Neonatorum. Sedangkan dari perhitungan uji korelasi dengan Koefisien Kontingensi didapatkan $\mathrm{C}=0.01$ yang berarti antara bayi berat badan lahir rendah dengan Sepsis Neonatorum mempunyai hubungan yang kurang erat. ${ }^{10}$

Penelitian yang dilakukan oleh Simbolon D di RSUD Curup Kabupaten Rejang Lebong (2008), hasil penelitian menunjukkan tidak ada hubungan berat badan lahir dengan kejadian sepsis neonatorurn. Hasil penelitian ini tidak 
sesuai dengan teori yang menyatakan bahwa bayi dengan BBLR berisiko tinggi mengalami infeksi atau sepsis seonatorum. Bayi BBLR berisiko mengalami sepsis neonatom karena pada bayi dengan BBLR pematangan organ tubuhnya (hati, paru, pencernaan, otak, daya pertahanan tubuh terhadap infeksi, dll) belum sempurna, maka bayi BBLR sering mengalami komplikasi yang berakhir dengan kematian. Pada bayi berat badan normal, minggu pertama setelah lahir berat bayi akan turun, kemudian akan naik sesuai dengan pertumbuhan bayi. Pada BBLR menurunnya berat badan bayi dapat terjadi setiap saat, karena biasanya ada masalah pemberian air susu ibu (ASI). Akibat bayi kurang atau tidak mampu menghisap ASI, bayi menderita infeksi atau mengalami kelainan bawaan. Demikian iuga Manuaba menyatakan bahwa bayi BBLR pusat pengatur pernafasan belum sempurna, surfaktan paru-paru masih kurang, sehingga perkembangannya tidak sempurna, otot pernafasan dan tulang iga masih lemah yang mengakibatkan oksigen masuk ke otak kurang, jika oksigen (02) kurang maka kuman anaerob mudah berkembang menyebabkan mudah terjadi infeksi. ${ }^{11}$

\section{METODE PENELITIAN}

Penelitian ini merupakan penelitian bentuk analitik observasional dengan studi prospektif untuk menilai hubungan antara apgar skor dan berat badan lahir dengan sepsis neonatorum di Sub Bagian Neonati RSUP Prof.Dr.R.D Kandou Manado. Penelitian ini dilakukan selama bulan November 2012 sampai Januari 2013. Populasi dari penelitian ini semua bayi yang lahir di RSUP Prof.Dr.R.D Kandou Manado. Sampel penelitian adalah semua bayi tersangka sepsis yang dirawat di Sub Bagian Neonati RSUP Prof.Dr.R.D
Kandou Manado dengan jumlah sampel yang diperlukan sebanyak 50 sampel. Variabel bebas penelitian ini adalah Apgar skor dan berat badan lahir dengan variable terikat sepsis neonatorum.

Defenisi operasional adalah bayi yang lahir dengan nilai Apgar yang dihitung pada menit ke-1 dan menit ke-5 (Apgar $\leq 5$ rendah dan Apgar $>5$ normal, bayi dengan BBLR ( $<2500$ gram) dan BBL normal (>2500 gram). Bayi dengan tersangka sepsis jika terdapat 3 gejala klinik sepsis neonatorum, atau terdapat 1 faktor resiko mayor ditambah 2 faktor resiko minor. Bayi dengan terbukti sepsis jika didapatkan faktor resiko, gejala klinik dan 2 pemeriksaan laboratorium (+). Bayi tidak terbukti sepsis jika terdapat gejala klinik sepsis tetapi tidak terbukti pada pemeriksaan laboratorium.

Pengumpulan data yaitu data riwayat persalinan (Apgar skor, berat badan lahir), umur, jenis kelamin, pada bayi yang memenuhi kriteria penelitiaan serta hasil pemeriksaan laboratorium (darah lengkap, CRP, kultur darah). Data yang didapat kemudian dikelompokkan dan di analisis dengan menggunakan SPSS (Statistical Program For Social Science) versi 21 dengan uji Fisher Exact dan analisis regresi logistik multipel.

\section{HASIL PENELITIAN}

Pada penelitian ini didapatkan jumlah bayi dengan tersangka sepsis sebanyak 50 bayi, dimana 40 bayi sepsis dan 10 bayi tidak terbukti sepsis.

Hubungan antara Apgar skor menit ke-1, Apgar skor menit ke-5 dan berat badan lahir dengan sepsis dapat dilihat pada tabel dibawah ini. 
Tabel 2. Sebaran bayi berdasarkan kategori Apgar menit ke-1 (rendah,normal) dengan kejadian sepsis.

\begin{tabular}{lccc}
\hline Kategori & Sepsis & Tidak Sepsis & Jumlah \\
\hline Rendah & $32(80)$ & $5(50)$ & $37(74)$ \\
Normal & $8(20)$ & $5(50)$ & $13(26)$ \\
\hline Jumlah & $40(100)$ & $10(100)$ & $50(100)$ \\
\hline
\end{tabular}

Tabel 3. Sebaran bayi berdasarkan kategori Apgar menit ke-5 (rendah,normal) dan kejadian sepsis.

\begin{tabular}{cccc}
\hline Kategori & Sepsis & Tidak Sepsis & Jumlah \\
\hline Rendah & $25(62,5)$ & $5(50)$ & $30(60)$ \\
Normal & $15(37,5)$ & $5(50)$ & $20(40)$ \\
\hline Jumlah & $40(100)$ & $10(100)$ & $50(100)$ \\
\hline
\end{tabular}

Tabel 4. Sebaran bayi berdasarkan berat badan lahir dengan kejadian sepsis

\begin{tabular}{cccc}
\hline Kategori & Sepsis & Tidak Sepsis & Jumlah \\
\hline BBL rendah & $6(85,7)$ & $1(14,3)$ & $7(100)$ \\
BBL normal & $34(79,1)$ & $9(20,9)$ & $43(100)$ \\
\hline Jumlah & $40(80)$ & $10(20)$ & $50(100)$ \\
\hline
\end{tabular}

Tabel 5. Hasil uji hubungan Apgar Skor, BBL dengan kejadian Sepsis

\begin{tabular}{lcc}
\hline Model (variable) & Koefisien regresi & $\mathrm{P}$ \\
\hline Apgar skor menit ke-1 & .473 & 0,712 \\
Apgar skor menit ke-5 & 10.003 & 0,999 \\
Berat badan lahir & -10.058 & 0,999 \\
\hline Constant & 20.556 & 0,999 \\
\hline
\end{tabular}

\section{BAHASAN}

\section{Hubungan Apgar skor dengan sepsis}

Apgar skor di bedakan menjadi Apgar skor menit ke-1 dan Apgar skor menit ke-5.

Apgar skor menit ke-1 dengan sepsis Pada Apgar skor menit ke-1 dengan sepsis dengan uji Fisher Exact diperoleh nilai $\mathrm{p}=$ $0,067>\alpha=0,05$. Hasil ini menunjukkan tidak ada hubungan Apgar skor menit ke-1 dalam bentuk kategori rendah dan normal dengan kejadian sepsis. Jumlah Apgar skor pada bayi yang tidak sepsis memiliki jumlah Apgar skor rendah dan Apgar skor normal yang sama. Hal ini menunjukkan Apgar skor rendah dapat terjadi pada pasien tidak sepsis. Tetapi berdasarkan data diperolah persentase bayi dengan sepsis memiliki Apgar skor rendah lebih banyak dibandingkan bayi dengan tidak sepsis, dengan persentase sebesar 80 persen. 
Apgar skor menit ke-5 dengan sepsis

Pada Apgar skor menit ke-5 dengan sepsis dengan uji Fisher Exact diperoleh nilai $\mathrm{p}=$ $0,355>\alpha=0,05$. Hasil ini menunjukkan tidak ada hubungan Apgar skor menit ke-5 dalam bentuk kategori rendah dan normal dengan kejadian sepsis. Jumlah Apgar skor pada bayi yang tidak sepsis memiliki jumlah Apgar skor rendah dan Apgar skor normal yang sama. Hal ini menunjukkan Apgar skor rendah dapat terjadi pada pasien tidak sepsis. Tetapi berdasarkan tabel diperolah persentase bayi dengan sepsis memiliki Apgar skor rendah lebih banyak dibandingkan bayi dengan tidak sepsis, dengan persentase sebesar 62,5 persen.

Dengan uji Fisher Exact menunjukkan bahwa tidak ada hubungan antara Apgar skor menit ke-1 dan Apgar skor menit ke-5 dalam bentuk kategori rendah dan normal dengan kejadian sepsis. Tetapi dari data diperoleh bayi dengan sepsis memiliki Apgar skor rendah lebih banyak dibandingkan dengan bayi tidak sepsis. Hal ini sesuai dengan teori yaitu Apgar skor rendah beresiko terhadap kejadian sepsis.

\section{Berat badan lahir dengan sepsis}

Dari hasil uji Fisher Exact diperoleh nilai $\mathrm{p}=0,571>\alpha=0,05$. Hasil ini menunjukkan bahwa tidak ada hubungan berat badan lahir dalam bentuk kategori rendah dan normal dengan kejadian sepsis. Tetapi dari tabel diperoleh bayi dengan sepsis memiliki berat badan lahir rendah lebih banyak dengan persentase 85,7 persen. Penelitian ini sama dengan penelitian yang dilakukan oleh Simbolon D (2008), hasil penelitian menunjukkan tidak ada hubungan berat badan lahir dengan kejadian sepsis neonatorurn. Bayi BBLR berisiko mengalami sepsis neonatom karena pada bayi dengan BBLR pematangan organ tubuhnya (hati, paru, pencernaan, otak, daya pertahanan tubuh terhadap infeksi, dll) belum sempurna, maka bayi BBLR sering mengalami komplikasi yang berakhir dengan kematian. Penelitian ini berbeda dengan penelitian Raden NS tentang pengaruh antara berat badan bayi dengan terjadinya sepsis. Dengan uji Chi Square dan uji Koefisien Kontingensi. Hasil penelitian dengan metode Chi Square didapatkan ada hubungan antara bayi berat badan lahir rendah dengan Sepsis Neonatorum. Sedangkan dari perhitungan uji korelasi dengan Koefisien Kontingensi didapatkan antara bayi berat badan lahir rendah dengan Sepsis Neonatorum mempunyai hubungan yang kurang erat.

\section{Hubungan Apgar skor dan berat badan lahir dengan sepsis}

Berdasarkan data diperoleh bayi sepsis neonatorum memiliki Apgar skor rendah dan berat badan lahir rendah dengan persentase terbanyak dibandingkan bayi dengan Apgar skor normal dan berat badan lahir normal. Hasil analisis regresi logistik multipel (melibatkan variable Apgar skor menit pertama dan menit kelima dan berat badan lahir) hasil analisis ini menunjukkan bahwa secara bersamasama, Apgar skor menit pertama dan menit kelima dan berat badan lahir tidak berhubungan bermakna dengan kejadian sepsis $(P>0,05)$. Nilai koefisien korelasi multipelnya $(\mathrm{R})=0,377$.

\section{SIMPULAN}

Dari hasil penelitian tentang hubungan Apgar skor dan berat badan lahir dengan sepsis neonatorum di Sub Bagian Neonati RSUP Prof.Dr.R.D.Kandou Manado bulan November 2012 sampai Januari 2013 dapat disimpulkan sebagai berikut : dari data diperoleh bayi dengan Apgar skor rendah dan berat badan lahir rendah memiliki persentase lebih banyak pada sepsis neonatorum. Dengan uji statistik didapatkan tidak ada hubungan bermakna antara Apgar skor dan berat badan lahir dengan sepsis neonatorum. 
Saran: Diharapkan adanya penelitian lebih lanjut mengenai hubungan apgar skor dan berat badan lahir dengan sepsis neonatorum untuk memperjelas seberapa besar hubungan antara apgar skor dan berat badan lahir terhadap kejadian sepsis

\section{UCAPAN TERIMA KASIH}

Ucapan terima kasih ditujukan kepada dr. Stefanus Gunawan, $\operatorname{SpA}(\mathrm{K})$, MSi.Med dan dr. Novie H. Rampengan, SpA selaku penguji skripsi yang telah memberikan banyak masukan dan saran, serta pihak-pihak yang secara langsung atau tidak langsung telah menumbuhkan gagasan dan ide kepada penulis

\section{DAFTAR PUSTAKA}

1. Deprtemen Kesehatan Republik Indonesia. Penatalaksanaan Sepsis Neonatorum.2007.

2. Pusponegoro TS. Sepsis pada neonatus. Sari Pediatri. Vol 2.2000.

3. Aminullah Asril. Sepsis Pada Bayi Baru Lahir. Dalam : Kosim MS, Yunanto A, Dewi R, Sarosa GI, Usman A.Buku Ajar Neonatologi. Edisi I. Jakarta:2012.170-9.

4. BLU RSUP Prof.Dr.R.D.Kandou Manado. Panduan praktik klinik : Sepsis Neonatorum. 2012.

5. Sankar MJ, Agarwal R, Deorari AK, Paul VK. In: Sepsis in The Newborn. Devision of Neonatology. Departement of Pediatrics. All India Institute Sciences.New Delhi;2008.
6. Dharmasetiawani N. Asfiksia dan Resusitasi Bayi Baru Lahir. Dalam: Kosim MS, Yunanto A, Dewi R, Sarosa GI, Usman A. Buku ajar Neonatologi. Edisi I. Jakarta:IDA;2008.h 103-24.

7. Arvin BK. Wahab S editors. Ilmu Kesehatan Anak Nelson Vol.1. edisi ke 15.Jakarta:EGC;2000. h 541-3; 635.

8. Damanik SM. Klasifikasi Bayi Menurut Berat Lahir dan Masa Gestasi. Dalam: Kosim MS, yunanto A, Dewi R, Sarosa GI, Usman A. Buku Ajar Neonatologi. Edisi I. Jakarta:IDAI;2012.h11-17.

9. Festy P. Analisis Faktor Resiko pada Kejadian Berat Badan Lahir Rendah di Kabupaten Sumenep. Fakultas Kedokteran UM Surabaya. Diunduh dari http://www.fik.umsurabaya.ac.id/jurnal/A NALISIS-FAKTOR-RESIKO-PADAKEJADIAN-BERAT-BADAN-LAHIRRENDAH-Di-KABUPATEN-

SUMENEP.pdf (tanggal: 3 Oktober 2012).

10. Raden NS. Pengaruh Berat Bada Lahir Dengan Terjadinya Sepsis.Surakarta:2008. Diunduhdari:http://digilib.uns.ac.id/penggun a.php?mn=showview\&id=9854 (tanggal 2 Januari 2013).

11. Simbolon D. Faktor Resiko pada Bayi Baru Lahir di RSUD Curup Kabupaten Rejang Lebong. Di unduh dari: http://isjd.pdii.lipi.go.id/admin/jurnal/3630 8127134_0125-9695.pdf. 